\title{
Factors Affecting Financial Reporting Quality (Study on the Provincial Government of Dki Jakarta)
}

\author{
Carolus Jeremy Jonathan J*, Jan Hoesada
}

Accounting Master Program Universitas Mercu Buana

DOI: $10.36348 / \mathrm{sb} .2020 . v 06 i 03.003$

| Received: 07.03.2020 | Accepted: 14.03.2020 | Published: 18.03.2020

*Corresponding author: Carolus Jeremy Jonathan J

\section{Abstract}

The purpose of this research is to obtain empirical evidence and examine the influence of organizational culture, transparency and weaknesses of the internal control system on the quality of financial reporting on Local Government Units in Capital Province of Jakarta. This research was conducted using quantitative survey methods with causality research design. The data used as research sourced from questionnaires. The population in this study is the Local Government Units in Capital Province of Jakarta. The sampling technique used was purposive sampling. Questionnaires were distributed to 36 local government units. Each Unit is given 2 (two) questionnaires for the financial department. Analysis and processing of data using the help of the statistical computer program SmartPLS v.3.2.8. The results obtained from the test show: (1) organizational culture significantly influence financial reporting quality, (2) transparency do not significantly influence financial reporting quality, (3) internal control system weakness significantly influence financial reporting quality.

Keywords: Organizational Culture, Transparency, Weaknesses of the Internal Control System, Quality of Financial Reporting.

Copyright @ 2020: This is an open-access article distributed under the terms of the Creative Commons Attribution license which permits unrestricted use, distribution, and reproduction in any medium for non-commercial use (NonCommercial, or CC-BY-NC) provided the original author and source are credited.

\section{INTRODUCTION}

As a form of accountability for the implementation of the Regional Income and Expenditure Budget (RIEB), the Regional Head submits a draft Regional Regulation on accountability for implementing the RIEB to the Regional House of Representatives (DPRD) in the form of financial reports that have been audited by the Audit Board of the Republic of Indonesia (ABRI) no later than 6 (six) months after the fiscal year end up. The financial statements in question include the realization of RIEB, balance sheet, cash flow statement, and notes to the financial statements attached with the financial statements of regionally-owned enterprises. The financial statements are prepared and presented in accordance with government accounting standards established by Government Regulations.

In realizing accountable and transparent financial statements, Government Regulation Number 24 of 2005 concerning Government Accounting Standards which amended to Government Regulation Number 71 of 2010 concerning Accrual-based
Government Accounting Standards. With the Government Accounting Standards, it is expected that each region will provide financial information that can be used for decision making. The central and regional governments must implement accrual-based Government Accounting Standards.

The ABRI, a state institution that is independent and free and has the authority to examine the management and responsibilities of state finances. Based on Law Number 15 of 2006 concerning the ABRI, the scope of ABRI audit includes the central government, regional governments, Bank Indonesia, other state institutions, BUMN, Public Service Board, BUMD, and all other institutions that manage state finances. Examinations conducted by ABRI include audits of performance, finance, and audits for specific purposes.

From the Summary Results of Semester II Examinations in 2017, the ABRI has reported 542 examination results on the Regional Government Financial Statements (hereinafter abbreviated RGFS) in 
2016. The ABRI states that all local governments have applied accrual-based accounting. The ABRI gave Unqualified Opinion (UO) on 378 (70\%) RGFS, Qualified Opinion (QO) on 141 (26\%) RGFS, and Disclaimer Opinion (DO) on 23 (4\%) RGFS.

Table-1: List of SAB Opinions in Java from 2012 2017

\begin{tabular}{|lcccccc|}
\hline List of Provinces in Java & $\mathbf{2 0 1 2}$ & $\mathbf{2 0 1 3}$ & $\mathbf{2 0 1 4}$ & $\mathbf{2 0 1 5}$ & $\mathbf{2 0 1 6}$ & $\mathbf{2 0 1 7}$ \\
\hline DKI Jakarta Province & UO & QO & QO & QO & QO & UO \\
West Java Province & UO & UO & UO & UO & UO & UO \\
Central Java Province & UO & UO & UO & UO & UO & UO \\
D.I. Yogyakarta Province & UO & UO & UO & UO & UO & UO \\
East Java Province & UO & UO & QO & UO & UO & UO \\
Banten Province & QO & DO & DO & QO & UO & UO \\
\hline
\end{tabular}

Source: IHPS I BPK RI, 2018

The Provincial Government of DKI Jakarta received QO opinion from BPK for 4 (four) years in a row. According to the 2018 Semester Examination Results (IHPS) I, the ABRI found significant problems in the management and financial accountability of the DKI Jakarta Provincial Government which included: (1) Non-compliance with the provisions of the Laws and Regulations on Revenue Management. (2) Inflating prices of procurement activities. (3) Weaknesses in the system of controlling the implementation of the revenue and expenditure budget.

From the explanation above, it can be seen that the quality of the DKI Jakarta Provincial Government's financial statements reflected in the opinion given by the ABRI and its findings from the results of the examination. Based on the results of the audit from ABRI, it can be concluded that the financial statement information has not been presented transparently. Then the still weak internal control in the Provincial Government of DKI Jakarta, so that the delegation of tasks becomes unstructured and cause mistakes in decision making.

The ABRI gave QO with the exception of the DKI Jakarta Provincial Government's Financial Statements for four consecutive years from 2013-2016, giving rise to an indication that for the next 3 (three) years the DKI Jakarta Provincial Government has not made improvements on the findings of the ABRI.

DKI Jakarta Province as the national capital is expected to be a benchmark for other regions. This is because DKI Jakarta Province has a role as a business center. DKI Jakarta also plays a role as a national economic driver because it provides the largest contribution to Gross Domestic Product compared to other provinces.

\section{LITERATURE REVIEW Organizational Culture}

Waldo in Sembiring [1] states that organization is a structure between personal relationships based on formal authority and habits in an administrative system. Robbins in Yadiati [2] explains that organizational culture is a system of shared meanings shared by members of an organization that distinguishes the organization from other organizations.

Hofstede, et al. [3] research aims to detect structural elements of culture and especially those that most strongly influence work situations in organizations or institutions. From his research created the results those elements of organizational culture that is the distance of strength, collectivism, masculinity, uncertainty avoidance, and discipline.

Then Gray [4] tried to examine the influence of culture previously studied by Hofstede on the development of accounting systems internationally. The results of his study identified the most important value dimensions at the level of the accounting subculture: uncertainty avoidance and individualism. Power distance and masculinity are significant only to a certain extent. But apparently, masculinity is less important in the accounting value system.

Based on the results of Gray's research, Sudarwan and Fogarty re-examined the research objects in Indonesia. Sudarwan and Fogarty [5] examined the accounting values that Gray had identified as being related to the cultural dimension studied by Hofstede. The results of his research found that the distance of power shows a positive relationship with conservatism and uniformity. Then there is a positive relationship between the uncertainty of avoidance of professionalism, conservatism, confidentiality and uniformity. There is a positive relationship between individualism and professionalism and conservatism while uniformity and confidentiality indicate a negative relationship. There is no relationship between masculinity and accounting values.

Then in research Chariri [6] related to Javanese culture in organizations states that organizational culture plays an important role in shaping the behavior of organizational members. Javanese culture has a complex code of ethics and respect, reflected in Javanese. The maintenance of peace and inner harmony is a priority in social relations in Javanese culture. Quality financial reporting is strongly influenced by the organizational culture of a company. Organizational culture that is built determines whether or not the company complies with laws and regulations.

\section{Transparency}

According to Law Number 14 of 2008, transparency is openness in carrying out the decision making process and openness in presenting material and relevant information about the company. In line with this, Government Regulation No. 71 of 2010 states that transparency, namely providing open and honest 
financial information to the community based on the consideration that the public has the right to openly and comprehensively acknowledge the government's responsibility in managing the resources entrusted to it and its compliance with regulations.

Then transparency is something that is mandatory and very necessary in every institution that has an interest in many people. This is a form of supervision of each of the actions of these institutions. According to Bennis, et al. [7] transparency means no guile or cover-up; open; honest; frankly.

According to Kaufmann and Weber [8] transparency is understood as a principle that is closely related to governance. Transparency plays a key role in rebuilding confidence in financial system stability. In line with that, according to Kristiansen, et al. [9] states that transparency can be defined as a legal, political, and institutional structure that makes information about the internal characteristics of government and society available to actors both inside and outside the domestic political system.

According to Williams [6], there are 4 (four) indicators related to disclosure, namely identification of the target audience, data relevance, encoding of information, distribution of information. Then according to McGaughey [10] there are 2 indicators relating to the clarity of information that is information can be identified, and the information can be understood by the recipient. According to Bushman, et al. [11] there are 3 (three) indicators included in the dimension of accuracy, namely the intensity of the acquisition of personal information, completeness of information, and validation of information.

\section{Weaknesses of Internal Control System}

According to Kieso, et al. [12] internal control is a process designed to provide reasonable guarantees regarding the achievement of objectives related to operations, reporting, and compliance. Accordingly, according to Arens, et al. [13] the internal control system consists of policies and procedures designed to provide management with reasonable confidence that the company is achieving its goals and objectives.

Based on Government Regulation Number 60 Year 2008, the Internal Control System is an integral process in actions and activities carried out continuously by the leadership and all employees to provide adequate confidence in the achievement of organizational goals through effective and efficient activities, financial reporting reliability, security of assets the state, and obedience to laws and regulations.

In Government Regulation Number 60 Year 2008 dimensions have been identified in the internal control system adopted from the Committee of Sponsoring Organizations of the Treadway Commission (COSO), namely the control environment, risk assessment, control activities, information and communication, and monitoring.

The weakness of the internal control system is interpreted as the weak dimensions caused by the construct. A weak control system means a weak control environment, risk assessment, control activities, information and communication, and monitoring.

Setiyawati [14] conducted a study to examine the effect of accountants' internal competence, manager's commitment to the organization and the implementation of internal control systems on the quality of financial statements. The results of his research indicate that the implementation of the Internal Control System does not affect the quality of financial reporting.

Nengzih [15] conducted a study to examine the relationship of corporate governance, internal control and voluntary disclosure and its impact on the performance of the hospital industry in Indonesia. Based on the results of his research In general, government hospitals, teaching hospitals and general hospitals are above average in implementing good corporate governance and internal control.

\section{Financial Reporting Quality}

The quality of financial statements can be interpreted as the quality of accounting. Van Beest, et al. in Yadiati [2] defines the quality of financial statements as a broad concept, not only referring to financial information, but also disclosure, as well as non-financial information that are useful for decision making.

Chalaki, et al. in Yadiati [2] define the quality of financial reporting as an accuracy with which financial reporting conveys information about company operations, specifically expected cash flows, to investors. 


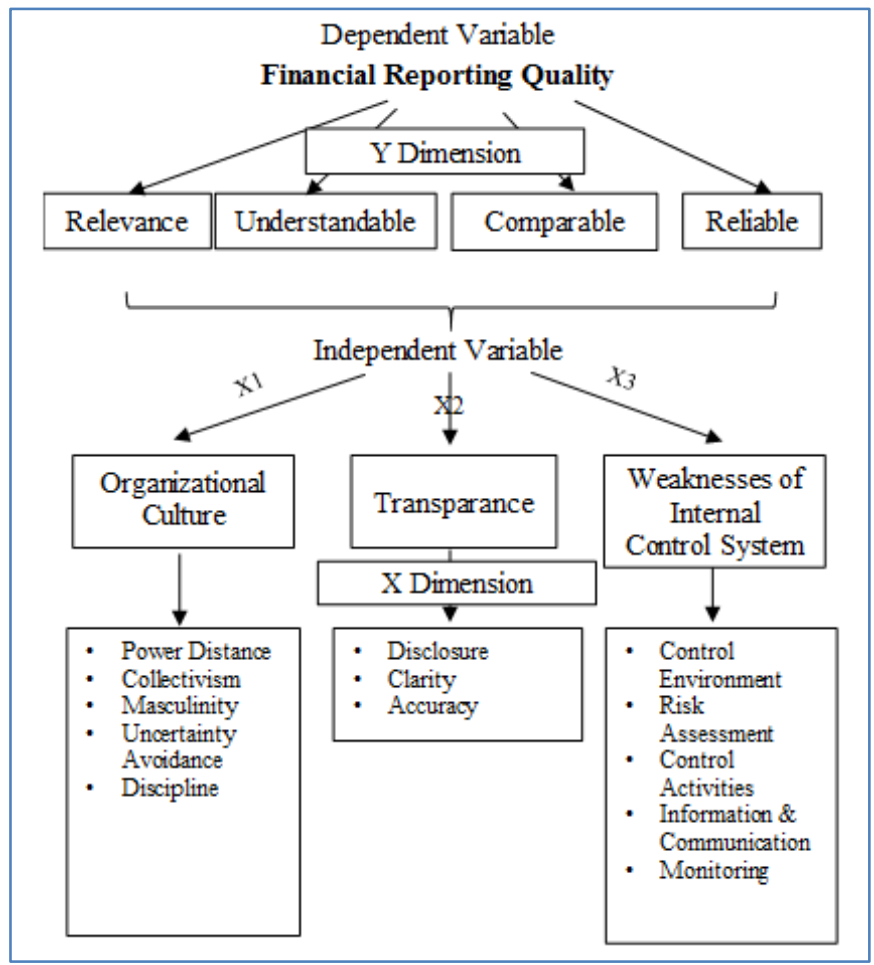

Fig-1: Framework

In achieving a quality financial report, within the scope of government prepared by the Government Accounting System that refers to Government Accounting Standards (GAS).

Based on Government Regulation Number 71 of 2010 concerning Government Accounting Standards, the dimensions of financial reporting quality are relevant, reliable, comparable, and understandable.

\section{RESEARCH METHOD}

\section{Type of Research}

This type of research is a quantitative method with a causality research design. The research data are primary data obtained by distributing questionnaires.

\section{Population and Sample}

The population in this study were all Regional Work Units (SKPD) in the DKI Jakarta Provincial Government, totaling 81 (eighty one) consisting of the Office, Agency, Secretariat, and Inspectorate. This research uses purposive sampling technique.

\begin{tabular}{|lr|}
\hline \multicolumn{1}{|c|}{ Keterangan } & Jumlah \\
\hline SKPD population in DKI Jakarta Province & 81 \\
Sample Criteria: & \\
- Excludes District SKPD & $(45)$ \\
\cline { 2 - 2 } Research sample & 36 \\
\hline
\end{tabular}

Fig-2: Basis of Sampling
This study selects respondents who in this case are directly related or responsible in making financial reports, and are very understanding of the accounting contained in each Regional Work Unit (SKPD). Each Regional Work Unit (SKPD) was chosen by 2 (two) people to become respondents, so the total respondents taken were 36 SKPD x 2 people $=72$ people.

\section{Developing Hypothesis}

The purpose of this study is to prove that organizational culture, transparency has a positive effect on the quality of LKPD, while the weakness of internal control negatively affects the quality of LKPD in the Provincial Government of DKI Jakarta. The following is the formulation of a hypothesis that will be verified:

H1: Organizational culture has a positive effect on the quality of RGFS

$\mathrm{H} 2$ : Transparency has a positive effect on the quality of RGFS

H3: Weaknesses of internal control negatively affect the quality of RGFS

\section{Validity and Reliability Test}

Validity test is seen in the convergence validity, namely the loading factor value which explains the relationship of the indicator with latent variables. Expected value $>0,7$, but for the first study loading values above 0,5 are still considered valid [16]. 
Then to test the reliability of the research measuring instrument, it is necessary to test the reliability of the construct by measuring the composite reliability and Cronbach's alpha of each indicator that measures the construct.

\section{Hypothesis test}

In this study, hypothesis testing was taken on the basis of the statistical value on the SmartPLS output results, after which it was compared with the $t_{\text {table }}$ at a significance level of $5 \%$. If the value of $t_{\text {count }}$ is greater than the value of the $t_{\text {table }}$ then the hypothesis is accepted, but if the value of $t_{\text {count }}$ is smaller than the value of the $t_{\text {table }}$ then the hypothesis is rejected.

\section{RESULT}

\section{Descriptive Statistical Analysis}

Tabel-2: Descriptive Analysis

\begin{tabular}{|c|c|c|c|c|c|}
\hline Variabel & Mean & Dimension & Mean & Indicator & Score \\
\hline \multirow{13}{*}{$\begin{array}{l}\text { 1. Organizational } \\
\text { Culture }\end{array}$} & \multirow[t]{13}{*}{4,20} & \multirow[t]{3}{*}{ 1. Power Distance } & \multirow[t]{3}{*}{4,21} & 1. Conformity & 4,38 \\
\hline & & & & 2. Dependency & 4,40 \\
\hline & & & & 3. Perspective & 3,85 \\
\hline & & \multirow[t]{3}{*}{ 2. Collectivism } & \multirow[t]{3}{*}{4,31} & 1. Priority of interest & 4,13 \\
\hline & & & & 2. Decision Considerations & 4,43 \\
\hline & & & & 3. Purpose & 4,39 \\
\hline & & \multirow[t]{2}{*}{ 3. Masculinity } & \multirow[t]{2}{*}{4,30} & 1. Management Role & 4,22 \\
\hline & & & & 2. Solution to problem & 4,38 \\
\hline & & \multirow{2}{*}{$\begin{array}{l}\text { 4. Uncertainty } \\
\text { Avoidance }\end{array}$} & \multirow[t]{2}{*}{4,12} & 1. Reason and Insight & 4,15 \\
\hline & & & & 2. Tolerance & 4,08 \\
\hline & & \multirow{3}{*}{ 5. Discipline } & \multirow[t]{3}{*}{4,08} & 1. Dicipline Priority & 4,00 \\
\hline & & & & 2. Obedience & 4,26 \\
\hline & & & & 3. Application & 3,99 \\
\hline \multirow[t]{9}{*}{ 2. Transparansi } & \multirow[t]{9}{*}{4,02} & \multirow[t]{4}{*}{ 1. Disclosure } & \multirow[t]{4}{*}{4,01} & 1. Identification & 3,99 \\
\hline & & & & 2. Information Relevance & 3,89 \\
\hline & & & & 3. Information Publication & 4,13 \\
\hline & & & & 4. Pemerataan Informasi & 4,04 \\
\hline & & \multirow[t]{2}{*}{ 2. Clarity } & \multirow[t]{2}{*}{4,00} & 1. Purpose and Objectives of & 4,07 \\
\hline & & & & 2. Comprehension & 3,93 \\
\hline & & 3. Accuracy & 4,05 & 1. Target & 4,06 \\
\hline & & & & 2. Testing & 4,08 \\
\hline & & & & 3. Completeness & 4,00 \\
\hline 3. Kelemahan Sistem & 2,07 & 1. Control & 2,11 & 1. Integrity & 1,76 \\
\hline Pengendalian & & Environment & & 2. Basic Decision & 1,79 \\
\hline Internal & & & & 3. Competence & 2,40 \\
\hline & & & & 4. Structure & 1,94 \\
\hline & & & & 5. Delegation of Authority & 2,44 \\
\hline & & & & 6. Suitability of the actual situ & 1,75 \\
\hline & & & & 7. Suitability of the regulation & 2,10 \\
\hline & & & & 8. Penalty & 2,68 \\
\hline & & 2. Risk Assessment & 2,13 & 1. Risk Identification & 2,01 \\
\hline & & & & 2. Identification of Risk Effec & 2,24 \\
\hline & & 3. Control Activities & 1,98 & 1. Scope of Activities & 1,90 \\
\hline & & & & 2. Assessment & 2,24 \\
\hline & & & & 3. Procedure Policy & 1,81 \\
\hline & & 4. Information and & 1,97 & 1. Application of ethical value & 2,31 \\
\hline & & Communication & & 2. Facilities and infrastructure & 1,82 \\
\hline & & & & 3. Data Relevance & 1,83 \\
\hline & & & & 4. Management and Develop & 1,90 \\
\hline & & 5. Monitoring & 2,16 & 1. Supervision & 2,49 \\
\hline & & & & 2. Procedure & 2,47 \\
\hline & & & & 3. Conformity of Evidence & 1,68 \\
\hline & & & & 4. Evaluation & 2,14 \\
\hline & & & & 5. Irrelevance & 2,04 \\
\hline 4. Kualitas Pelaporan & 4,13 & 1. Relevance & 4,15 & 1. Standard Conformity & 4,14 \\
\hline Keuangan & & & & 2. On Time & 4,19 \\
\hline & & & & 3. Statement & 4,11 \\
\hline & & 2. Reliable & 4,06 & 1. Transaction Reliability & 4,10 \\
\hline & & & & 2. Materiality & 3,97 \\
\hline & & & & 3. Purpose & 3,97 \\
\hline & & & & 4. Testing & 4,19 \\
\hline & & 3. Comparable & 4,18 & 1. Previous Period & 4,29 \\
\hline & & & & 2. Other Region & 4,07 \\
\hline & & 4. Understandable & 4,13 & 1. Classification & 4,19 \\
\hline & & & & 2. Clear and concise & 4,07 \\
\hline
\end{tabular}


Carolus Jeremy Jonathan J \& Jan Hoesada., Sch Bull, March 2020; 6(3): 67-75

Table 2 presents the results of processing scores on the questionnaires that have been collected. Scores are shown on each indicator and the mean produced on each dimension and variable.

\section{Validity Test}

Tabel-3: Validity Test Results

\begin{tabular}{|c|c|c|c|c|}
\hline Construct & Dimension & Indicator & $\begin{array}{l}\text { Loading } \\
\text { Factor }\end{array}$ & Description \\
\hline \multirow{5}{*}{$\begin{array}{l}\text { Organizational } \\
\text { Culture }\end{array}$} & 1. Power Distance & - Perspective & 1,000 & Valid \\
\hline & 2. Collectivism & - Priority of Interest & 1,000 & Valid \\
\hline & 3. Masculinity & $\begin{array}{l}\text { - Management Role } \\
\text { - Solution to Problem }\end{array}$ & $\begin{array}{l}0,724 \\
0,638\end{array}$ & $\begin{array}{l}\text { Valid } \\
\text { Valid }\end{array}$ \\
\hline & $\begin{array}{l}\text { 4. Uncertainty } \\
\text { Avoidance }\end{array}$ & $\begin{array}{ll}\text { - } & \text { Reason and Insight } \\
\text { - } & \text { Tolerance } \\
\end{array}$ & $\begin{array}{l}0,812 \\
0,624\end{array}$ & $\begin{array}{l}\text { Valid } \\
\text { Valid }\end{array}$ \\
\hline & 5. Dicipline & $\begin{array}{ll}\text { - } & \text { Dicipline Priority } \\
\text { - } & \text { Obedience } \\
\text { - } & \text { Application }\end{array}$ & $\begin{array}{l}0,792 \\
0,705 \\
0,622\end{array}$ & $\begin{array}{l}\text { Valid } \\
\text { Valid } \\
\text { Valid }\end{array}$ \\
\hline \multirow[t]{3}{*}{ Transparency } & 1. Disclosure & $\begin{array}{ll}\text { - Information Relevance } \\
\text { - } \text { Information Publication } \\
\end{array}$ & $\begin{array}{l}0,840 \\
0,844 \\
\end{array}$ & $\begin{array}{l}\text { Valid } \\
\text { Valid } \\
\end{array}$ \\
\hline & 2. Clarity & $\begin{array}{l}\text { - Purpose and Objectives of } \\
\text { Information }\end{array}$ & 1,000 & Valid \\
\hline & 3. Accuracy & $\begin{array}{ll}\text { - } & \text { Testing } \\
\text { - } & \text { Completeness }\end{array}$ & $\begin{array}{l}0,884 \\
0,835\end{array}$ & $\begin{array}{l}\text { Valid } \\
\text { Valid }\end{array}$ \\
\hline \multirow[t]{5}{*}{$\begin{array}{l}\text { Weaknesses in the } \\
\text { Internal Control } \\
\text { System }\end{array}$} & $\begin{array}{l}\text { 1. Control } \\
\text { Environment }\end{array}$ & $\begin{array}{ll}\text { - } & \text { Integrity } \\
\text { - } & \text { Basic Decision } \\
\text { - } & \text { Competence } \\
\text { - } & \text { Delegation of Authority } \\
\text { - } & \text { Suitability of the actual situation }\end{array}$ & $\begin{array}{l}0,801 \\
0,794 \\
0,528 \\
0,555 \\
0,792 \\
\end{array}$ & $\begin{array}{l}\text { Valid } \\
\text { Valid } \\
\text { Valid } \\
\text { Valid } \\
\text { Valid } \\
\end{array}$ \\
\hline & 2. Risk Assessment & - Identification of Risk Effects & 1,000 & Valid \\
\hline & $\begin{array}{l}\text { 3. Control } \\
\text { Activities }\end{array}$ & $\begin{array}{l}\text { - Scope of Activities } \\
\text { - Procedure Policy }\end{array}$ & $\begin{array}{l}0,834 \\
0,867\end{array}$ & $\begin{array}{l}\text { Valid } \\
\text { Valid }\end{array}$ \\
\hline & $\begin{array}{l}\text { 4. Information and } \\
\text { Communication } \\
\end{array}$ & $\begin{array}{l}\text { - Facilities and infrastructure } \\
\text { - Data Relevance }\end{array}$ & $\begin{array}{l}0,824 \\
0,805\end{array}$ & $\begin{array}{l}\text { Valid } \\
\text { Valid } \\
\end{array}$ \\
\hline & 5. Monitoring & $\begin{array}{ll}\text { - } & \text { Supervision } \\
\text { - } & \text { Procedure } \\
\text { - } & \text { Conformity of Evidence }\end{array}$ & $\begin{array}{l}0,707 \\
0,685 \\
0,736 \\
\end{array}$ & $\begin{array}{l}\text { Valid } \\
\text { Valid } \\
\text { Valid } \\
\end{array}$ \\
\hline \multirow[t]{4}{*}{$\begin{array}{l}\text { Financial Reporting } \\
\text { Quality }\end{array}$} & 1. Relevance & $\begin{array}{ll}\text { - } & \text { Standard Conformity } \\
\text { - } & \text { On Time } \\
\text { - } & \text { Statement } \\
\end{array}$ & $\begin{array}{l}0,788 \\
0,530 \\
0,732 \\
\end{array}$ & $\begin{array}{l}\text { Valid } \\
\text { Valid } \\
\text { Valid } \\
\end{array}$ \\
\hline & 2. Reliable & $\begin{array}{ll}\text { - } & \text { Transaction Reliability } \\
\text { - } & \text { Materiality } \\
\text { - } & \text { Purpose } \\
\text { - } & \text { Testing } \\
\end{array}$ & $\begin{array}{l}0,677 \\
0,685 \\
0,597 \\
0,752 \\
\end{array}$ & $\begin{array}{l}\text { Valid } \\
\text { Valid } \\
\text { Valid } \\
\text { Valid } \\
\end{array}$ \\
\hline & 3. Comparable & $\begin{array}{ll}\text { - } & \text { Previous Period } \\
\text { - } & \text { Other Region } \\
\end{array}$ & $\begin{array}{l}0,901 \\
0,686 \\
\end{array}$ & $\begin{array}{l}\text { Valid } \\
\text { Valid } \\
\end{array}$ \\
\hline & 4. Understandable & $\begin{array}{l}\text { - Classification } \\
\text { - Clear and concise }\end{array}$ & $\begin{array}{l}0,891 \\
0,842\end{array}$ & $\begin{array}{l}\text { Valid } \\
\text { Valid }\end{array}$ \\
\hline
\end{tabular}

The convergent value of validity on the variables of organizational culture, transparency, weaknesses of the internal control system and the quality of financial reporting are adequate in the valid category. This can be seen in the loading factor column above, convergent validity for loading factor in the second order is sufficient at the indicator value above 0.5 . This means that all loading factors are significant at the 0.5 level.

\section{Reliability Test}

Table-4: Reliability Test Results

\begin{tabular}{|l|r|r|}
\hline \multicolumn{1}{|c|}{ Construct } & $\begin{array}{c}\text { Composite } \\
\text { Reliability }\end{array}$ & $\begin{array}{c}\text { Cronbach's } \\
\text { Alpha }\end{array}$ \\
\hline Organizational Culture & 0,720 & 0,626 \\
\hline Transparency & 0,725 & 0,643 \\
\hline Weaknesses of Internal Control System & 0,831 & 0,804 \\
\hline Financial Reporting Quality & 0,861 & 0,820 \\
\hline
\end{tabular}

Based on the reliability test results table, for composite reliability above 0.7 and Cronbach's alpha above 0.6 indicates that the reliability is good enough to be able to measure the construct. 


\section{Goodness Fit Test}

Tests conducted on the model goodness fit test can be seen in the $\mathrm{R}_{\text {-square }}$ value and $\mathrm{Q}$-square value, namely the prediction relevance test.
Tests conducted on the structural model can be seen in the R-square value, namely the goodness fit model and the Q-square value.

Table-5: Goodness Fit Test Results

\begin{tabular}{|c|c|c|}
\hline Variable & $\boldsymbol{R}$-Square & $\boldsymbol{Q}$-Square \\
\hline Financial Reporting Quality & 0,645 & 0,211 \\
\hline
\end{tabular}

This explains that the construct variable of financial reporting quality of $64.5 \%$ is influenced by the construct of organizational culture, transparency, and weaknesses of the internal control system. Then the remaining $35.5 \%$ is influenced by other variables outside this research.

Meanwhile the predictive value of relevance $(\mathrm{Q}$-square $)$ in the structural model is 0.211 , meaning that this model is able to explain the variable quality of financial reporting.

\section{HYPOTHESIS TEST}

Hypothesis testing is taken on the basis of the $t_{\text {statistic }}$ value on the SmartPLS output results, after which it is compared with the $t_{\text {table }}$ at a significance level of $5 \%$. If the value of $t_{\text {count }}$ is greater than the value of the $\mathrm{t}_{\text {table }}$ then the hypothesis is accepted, but if the value of $t_{\text {count }}$ is smaller than the value of the $t_{\text {table }}$ then the hypothesis is rejected.

Tabel-6: Hypothesis Test Results

\begin{tabular}{|l|r|r|r|r|r|}
\hline Variable & $\begin{array}{c}\text { Original } \\
\text { Sample } \\
(\mathbf{O})\end{array}$ & $\begin{array}{c}\text { Sample } \\
\text { Mean } \\
(\mathbf{M})\end{array}$ & $\begin{array}{c}\text { Standar } \\
\text { De viation } \\
(\text { STDEV })\end{array}$ & Tstatistic & P Values \\
\hline OC $\rightarrow$ FRQ & 0,235 & 0,209 & 0,127 & 1,848 & 0,033 \\
\hline TRSP $\rightarrow$ FRQ & 0,062 & 0,096 & 0,117 & 0,534 & 0,297 \\
\hline WICS $\rightarrow$ FRQ & $-0,648$ & $-0,624$ & 0,154 & 4,196 & 0,000 \\
\hline
\end{tabular}

The coefficient parameter of organizational culture is 0,235 . This indicates that there is a positive influence of organizational culture on the quality of financial reporting. This means that every 1 (one) increase in organizational culture, the quality of financial reporting will increase by 0.235 .

The tstatistic value of organizational culture is 1,848 and Pvalues is 0,033 with a significance level of $5 \%(1,660)$, so it can be concluded that organizational culture has a significant effect on the quality of financial reporting.

The transparency parameter coefficient is 0,062 . The transparency tstatistic value is 0,534 and the Pvalues value is 0,297 with a significance level of 5\% $(1,660)$, so that the conclusion is rejected hypothesis. This means that transparency does not significantly influence the quality of financial reporting.

The coefficient parameter of the weakness of the internal control system is $-0,648$. This indicates that there is a negative influence on the weakness of the internal control system on the quality of financial reporting. This means that every 1 (one) increase in the weakness of the internal control system, the quality of financial reporting decreases by 0,648 .
The tstatistic value of the weakness of the internal control system is 4,196 and the value of Pvalues is 0.000 with a significance level of $5 \%$ $(1,660)$, so it can be concluded that the weakness of the internal control system has a significant effect on the quality of financial reporting.

\section{DISCUSSION \\ Organizational Culture}

Based on the results of research conducted, organizational culture has a positive and significant effect on the quality of financial reporting. This proves that organizational culture will shape the values of beliefs and behavior with members of the organization. These values and behavior then influence all company activities including activities in shaping financial reporting.

If seen in table 2: Descriptive Analysis, perspective indicators on the dimensions of strength distance and indicators of application to the dimensions of discipline show a score below 4. This indicates that the perspective of the strength of the power distance between subordinates and superiors. Then the application of discipline still has doubts that the application of discipline has not been fully implemented optimally. 
In line with Hofstede's [3] research, if the distance of strength is high, superiors and subordinates consider each other as existentially unequal. The hierarchical system is based on existential inequality. The relationship between subordinates and superiors in organizations with high power distance, often laden with emotion because it does not create the ideal perspective of superiors for subordinates. Superiors are entitled to privileges, and contact between superiors and subordinates can only be done by superiors. Then with the creation of these conditions, then ideologically subordinates will completely reject the authority of the boss so that it affects the discipline of his subordinates.

The results of this study support the research of Sudarwan and Fogarty [5] that the dimensions of power distance, uncertainty avoidance, and individualism studied in organizational culture have a positive effect on accounting values. But for the dimension of masculinity there is no influence on accounting values. Research Hesampanah, et al. [17] who examined the ethical perspective of financial management found positive results on financial reporting.

\section{Transparency}

Based on the results of research conducted, transparency does not affect the quality of financial reporting. Significance that occurs is due to the fact that there is still some information that has not been published, and then the information that has been presented is also inadequate and right on target. In this case, local governments have not yet realized the importance of transparency in improving the quality of financial reporting. The obligation of regional governments to present financial reports transparently has not yet been fully implemented. Other than that, the opinion of the Supreme Audit Board does not aim to state whether or not a financial statement is true, but only to state whether or not a financial statement is reasonable. So as to create the view that whether or not transparent financial statements do not affect its quality.

In line with the results of research on transparency, this may be due to the influence of the high power distance created between superiors and subordinates and causes the low application of discipline that can affect rejection of superior authority.

When seen in table 2: Descriptive Analysis, indicators of identification and relevance of information on the dimensions of disclosure as well as indicators of understanding on the clarity dimension show results below 4. This indicates that employees do not understand the identification and relevance of information to be published, which may be due to limitations the quality of its human resources.
The results of this study are in line with research by Kristiansen, Dwiyanto, Pramusinto and Putranto [9] that the level of transparency is still low due to some information that is not available to the public, as well as the assumption that the regional budget is still confidential. But not in line with research Hunton, Libby, and Mazza [18] states that transparency affects earnings management. The higher transparency will further reduce earnings management.

\section{Weaknesses of Internal Control System}

Based on the results of research conducted, the weakness of the internal control system has a negative and significant effect on the quality of financial reporting. This proves that weaknesses in control procedures can create a high risk of fraud and raise doubts about financial data, both in terms of recording, the existence of a transaction, and the identification of the risk of misstatement. In other words, the weak internal control in an organization will reduce the quality of financial reporting.

Improvements to the internal control system in local governments continue to be made. Periodic evaluations of the internal control system continue to be conducted to minimize the weaknesses in the internal control system. This can be seen in the results of the ABRI report the following year that the DKI Jakarta Provincial Government Financial Report received UO opinion.

The results of this study are in line with Kewo research [19] that the application of internal control affects financial accountability. But not in line with the research Setiyawati [14] states that there is no relationship between the implementation of the internal control system and the quality of financial reporting.

\section{CONCLUSION, LIMITATION AND PRACTICAL CONTRIBUTION}

Organizational culture plays a role in improving the quality of financial reporting. This can be seen in the financial statements of the provincial government of DKI in the following year which received an unqualified opinion from the ABRI.

Transparency does not affect the quality of financial reporting. This is due to the fact that there is still some information that hasn't been published yet, and the information that has been presented is inadequate and right on target.

Weaknesses of internal control system have a negative and significant effect on the quality of financial reporting. This indicates that any increase that occurs due to the weakness of the internal control system will cause the quality of financial reporting to decline. 
This research is expected to contribute to local governments as input for evaluating to improve the quality of financial reporting.

Limitations in this research that there are only 3 (three) variables that affect the quality of financial reporting, and the lack of research samples which only 72 samples. So it is hoped for further research can take more variables and samples.

\section{REFERENCES}

1. Sembiring, M. (2012). Budaya \& Kinerja Organisasi. Bandung: Fokusmedia.

2. Yadiati, W., \& Mubarok, A. (2017). Kualitas Pelaporan Keuangan: Kajian Teoretis dan Empiris. Jakarta: Kencana.

3. Hofstede, G., Hofstede, G.J., \& Minkov, M. (2010). Cultures and Organizations: Software of the Mind. New York: McGraw-Hill.

4. Gray, S. J. (1988). Towards a theory of cultural influence on the development of accounting systems internationally. Abacus, 24(1), 1-15.

5. Sudarwan, M., \& Fogarty, T. J. (1996). Culture and accounting in Indonesia: an empirical examination. The International Journal of Accounting, 31(4), 463-481.

6. Rachman, N., \& Andrianto, M. (2015). Implementasi Peraturan Pemerintah Nomor 60 Tahun 2008 Tentang Sistem Pengendalian Intern Pemerintah terhadap Satuan Kerja Perangkat Daerah pada Pemerintah Daerah untuk Mewujudkan Good Governance (Studi di Kantor Inspektorat Kota Kediri). Kumpulan Jurnal Mahasiswa Fakultas Hukum.

7. Bennis, W., O’Toole, J., \& Goleman, D. (2009). Transparansi: Bagaimana Pemimpin Menciptakan Budaya Keterbukaan. Penerjemah Irine Yovita. Jakarta: Libri.

8. Republik Indonesia. (2010). Peraturan Pemerintah Nomor 71 tahun 2010 tentang Standar Akuntansi Pemerintahan.

9. Kristiansen, S., Dwiyanto, A., Pramusinto, A., \& Putranto, E. A. (2009). Public sector reforms and financial transparency: Experiences from
Indonesian districts. Contemporary Southeast Asia, 64-87.

10. Jensen, M. C., \& Meckling, W. H. (1979). Theory of the firm: Managerial behavior, agency costs, and ownership structure. In Economics social institutions (pp. 163-231). Springer, Dordrecht.

11. McGaughey, R. E. (2002). Benchmarking business- to- business electronic commerce. Benchmarking: $\quad$ An International Journal.

12. Kieso, D.E., Weygandt, J.J., \& Kimmel, P.D. (2015). Accounting Principles (12th ed). USA: John Wiley and Sons.

13. Arens, A.A., Elder, R.J., \& Beasley, M.S. (2012). Auditing and Assurance Services (14th ed). New Jersey: Pearson Education, Inc.

14. Setiyawati, H. (2013). The effect of internal accountants' competence, managers' commitment to organizations and the implementation of the internal control system on the quality of financial reporting. International Journal of Business and Management Invention, 2(11), 19-27.

15. Nengzih. (2014). Corporate Governance, Internal Control and Voluntary Disclosures of Environmental Accounting to Company Performance: Evidence from Hospital Industries in Indonesia. Research Journal of Finance and Accounting, 5(22).

16. Wati, L. N. (2018). Metodologi Penelitian Terapan. Bekasi: CV. Pustaka Amri.

17. Hesampanah, H. S., Zabihmanesh, M., Hamehkhani, S. (2013). The Investigation Impact Ethical Perspective of Financial Management on Financial Reports. Journal of Basic and Applied Scientific Research. J. Basic. Appl. Sci. Res, 3(3)475-479.

18. Hunton, J. E., Libby, R., \& Mazza, C. L. (2006). Financial reporting transparency and earnings management (retracted). The Accounting Review, 81(1), 135-157.

19. Kewo, C.L. (2017). The Influence of Internal Control Implementation and Managerial Performance on Financial Accountability Local Government in Indonesia. International Journal of Economics and Financial Issues, 7(1), 293-297. 